\title{
FIRST RECORDS OF THE LICHEN SEPTOTRAPELIA USNICA (LECANORALES, ASCOMYCOTA) FROM WEST AFRICA
}

\author{
Martin KuKwa \& Marcin PiąTeK
}

\begin{abstract}
Septotrapelia usnica (Sipman) Kalb \& Bungartz is reported as new for West Africa from Togo. Its taxonomy, distribution and habitat requirements are discussed. Notes on other usnic acid-containing leprose species are presented.
\end{abstract}

Key words: biogeography, Lepraria, lichenized fungi, Nelsenium, Pilocarpaceae

Martin Kukwa, Department of Plant Taxonomy and Nature Conservation, University of Gdańsk, Wita Stwosza 59, 80-308 Gdańsk, Poland; e-mail:dokmak@ug.edu.pl

Marcin Piatek, Departament of Mycology, W. Szafer Institute of Botany, Polish Academy of Sciences, Lubicz 46, 31 -512 Kraków, Poland; e-mail: m.piatek@botany.pl

The leprose growth form (i.e., thallus completely composed of granules held together by prothalline or hypothalline hyphae) has independently evolved in several lineages of Ascomycota, apparently as an adaptation to a particular ecological niche. In the past, species with such a thallus morphology were ascribed mostly to the genus Lepraria Ach., but recent molecular phylogenetic studies indicate that Lepraria is polyphyletic, and several taxa have been transferred to other genera such as Andreiomyces Hodkinson \& Lendemer, Botryolepraria Canals et al., Caloplaca Th. Fr., Lecanora Ach. and Leprocaulon Nyl. (e.g., Ekman \& Tønsberg 2002; Grube et al. 2004; Nelsen et al. 2008; Kukwa \& Pérez-Ortega 2010; Bungartz et al. 2013; Hodkinson \& Lendemer 2013; Lendemer \& Hodkinson 2013). This segregation is not finished yet and some species may represent further evolutionary lineages unrelated to Lepraria s.str. (Ekman \& Tønsberg 2002; Nelsen et al. 2008).

Lepraria usnica Sipman is such a case. This lichen contains usnic acid and zeorin, and although morphologically it resembles other species of the genus Lepraria s.str. it was found to represent a leprarioid lineage within the family Pilocarpaceae (Lecanorales) (Nelsen et al. 2008), for which a new monotypic genus, Nelsenium Lendemer \& Hod- kinson, was recently introduced by Lendemer and Hodkinson (2013). This name became a synonym of Septotrapelia Aptroot \& Chaves, however, as fertile material of L. usnica with apothecia was found in Ecuador, confirming its placement within this genus (Bungartz et al. 2013).

Septotrapelia usnica (Sipman) Kalb \& Bungartz has been reported from scattered localities in the tropics, with two records from the southern part of the African mainland (Namibia, South Africa) (Sipman 2003, 2004; Elix 2006; Nelsen et al. 2008; Bungartz et al. 2013). In this paper we extend its known distribution to West Africa.

The material on which our study is based is deposited in KRAM and UGDA. Lichen metabolites necessary for determination of the species were identified using thin layer chromatography (TLC) in solvents A, B' and C, according to Orange et al. (2001).

Septotrapelia usnica (Sipman) Kalb \& Bungartz in Bungartz et al., Phytotaxa 150(1): 11. 2013. - Lepraria usnica Sipman, Biblioth. Lichenol. 86: 179. 2003. - Nelsenium usnicum (Sipman) Lendemer \& Hodkinson, Mycologia 105(4): 1013. 2013.

This is a crustose, mostly sterile, leprose species with very small marginal lobes (microsquamules). 
These marginal lobes are irregular, up to $c a 0.2$ mm wide, with raised margins. The thallus spreads by dispersed or clustered granules which secondarily aggregate to a continuous layer. The granules are initially small, (40-)70-170(-200) $\mu \mathrm{m}$ in diameter, and soon become pseudocorticate, compact and very coarse to almost subsquamulose, (220-)245-420(-580) $\mu \mathrm{m}$ in diameter, then secondarily forming soredia (Sipman 2003, 2004; Bungartz et al. 2013).

SeCONDARY Chemistry. The species always produces usnic acid and zeorin in large quantities, and small to trace amounts of isousnic and placodiolic acids, contortin and some xanthones (the latter detected only by HPLC) (Sipman 2003, 2004; Elix 2006). Based on the presence of some additional substances, Elix (2006) distinguished three chemotypes: the first with hopane-16 $\beta, 22-$ diol (large or small amounts), the second with \pm roccellic acid (trace amount), and the third with atranorin and chloroatranorin (both in small amounts). Our specimen contained one spot of terpenoid at a high concentration. Most probably this spot represented hopane-16 3,22 -diol, but we hesitate to specify this terpenoid because we had no extract of it for comparison.

Comments. Septotrapelia usnica can be mistaken for three species of Lepraria s.1. containing usnic acid and zeorin: L. ecorticata (J. R. Laundon) Kukwa, L. leuckertiana (Zedda) L. Saag and L. straminea Vain. Lepraria ecorticata develops elobate thalli without a medulla and prothallus, which consist of well separated granules, whereas the thalli of L. leuckertiana are cottony, obscurely lobed, with a thick medulla and granules intermixed with abundant medullary hyphae and not well separated. The Antarctic L. straminea differs in having corticated, coarse granules and its thallus resembles the L. neglecta group (Laundon 2003; Sipman 2003, 2004; Kukwa 2006; Saag et al. 2009; Osyczka et al. 2010; Flakus et al. 2011). All of these species are suspected to be unrelated to Lepraria s.str. but their phylogenetic position has not been resolved yet (Nelsen et al. 2008; Osyczka et al. 2010; Lendemer \& Hodkinson 2013).
In addition to the above-mentioned three $L e$ praria s.l. species, two taxa of Leprocaulon with Lepraria-like thalli also contain usnic acid and zeorin: Leprocaulon coriense (Hue) Lendemer \& Hodkinson [syn. Lepraria coriensis (Hue) Sipman] and L. knudsenii Lendemer \& Hodkinson. Leprocaulon coriense has larger ( $>0.5 \mathrm{~mm}$ wide), regular and rounded lobes which are smooth near the margin, with more or less scattered granules in the center, and in addition to zeorin and usnic acids this species produces protodehydroconstipatic and constipatic acids (Laundon 2003; Sipman 2003, 2004; Elix 2006; Kukwa 2006; Saag et al. 2009; Flakus et al. 2011; Bungartz et al. 2013; Lendemer \& Hodkinson 2013). The thallus of Leprocaulon knudsenii is always elobate and composed of granules of smaller size (30-81 $\mu \mathrm{m}$ diam.). The granules are initially isolated but later become aggregated but still visibly separate from each other (Lendemer \& Hodkinson 2013).

Ecology. The species usually is collected from rocks and soil but is also found rarely on tree bark. It grows in disturbed or undisturbed forests and open stands (grassland, roadsides, rocky outcrops) from dry to humid habitats (Sipman 2003, 2004; Bungartz et al. 2013).

In Togo, Septotrapelia usnica was found at two distant localities in the Togo Mountains (Chaîne $\mathrm{du}$ Togo). In the Kara Region it was found in the dry Sudanian savanna zone on artificially exposed NW-facing rock in a semi-shaded place under cover of a Bombax costatum Pellegr. \& Vuill. tree (Fig. 1A \& B). In the Plateaux Region, S. usnica was found in the Guinean forest-savanna mosaic zone on naturally exposed $\mathrm{N}$-facing rock in a fully shaded and moderately moist place, forming a community with Begonia rostrata Welw. ex Hook.f. and Selaginella sp., two typically moisture- and shade-preferring plants (Fig. 1C \& D).

Distribution. Septotrapelia usnica is very widely distributed in the tropics and may consist of several cryptic species (Bungartz et al. 2013). Up to now it was recorded in Africa (Namibia, Seychelles and South Africa), Asia (Indonesia, Singapore and Sri Lanka), Australia, North America (El Salvador and Panama) and South America 

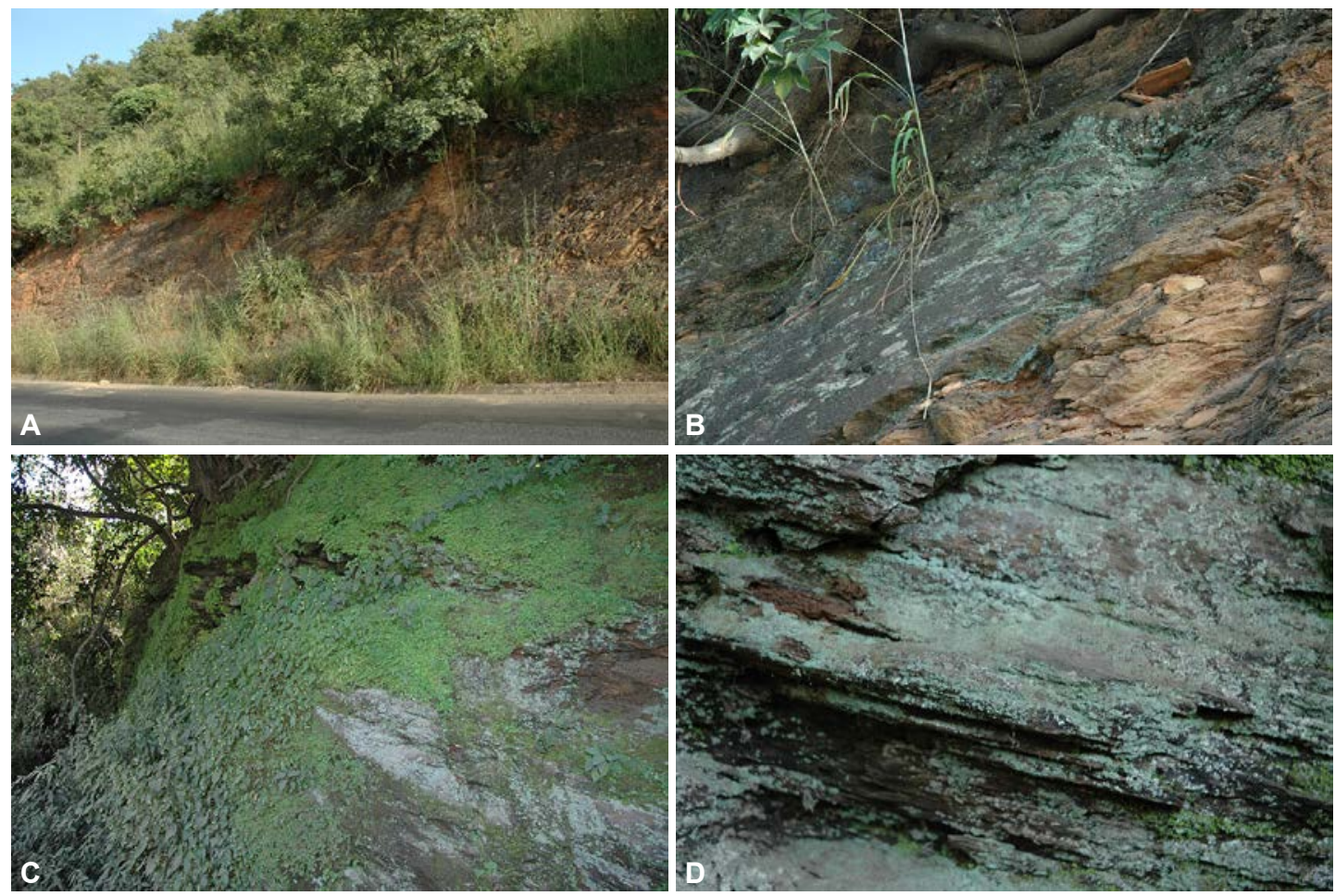

Fig. 1. Habitat and specimens of Septotrapelia usnica (Sipman) Kalb \& Bungartz in Kara Region (A \& B) and Plateaux Region (C \& D), Togo. Photo M. Piątek.

(Colombia, continental Ecuador and Galapagos Islands) (Sipman 2003, 2004; Elix 2006; Nelsen et al. 2008; Bungartz et al. 2013), and South Atlantic Islands (Ascension Island, St Helena) (Aptroot 2008). In this paper the species is reported for the first time from Togo, from two localities. These records are the first from West Africa.

Specimens examined. TOGO. Kara Region: between Défalé and Kandé, ca $6 \mathrm{~km}$ SE of Kandé, $09^{\circ} 55^{\prime} 14.5^{\prime \prime} \mathrm{N}, 01^{\circ} 05^{\prime} 44^{\prime \prime} \mathrm{E}$, elev. ca $325 \mathrm{~m}$, on rock, 31 Oct. 2011, M. Piatek s.n. (KRAM L-65973, UGDA L-19023); Plateaux Region: between Imoussa and Ounabe, ca $12 \mathrm{~km} \mathrm{~W}$ of Atakpamé, $07^{\circ} 33^{\prime} 36^{\prime \prime} \mathrm{N}$, $01^{\circ} 01^{\prime} 12^{\prime \prime}$, elev. ca $470 \mathrm{~m}$, on rock, 4 Nov. 2011, M. Piatek s.n. (KRAM L-65974, UGDA L-19024).

Acknowledgements. We thank Atse K. Guelly (University of Lomé, Togo) and Nourou S. Yorou (University of Parakou, Benin) for their help during the collecting trip, and the anonymous reviewer for helpful remarks on the manuscript. The field work in
Togo by MP was supported by the National Science Center (NCN) of Poland (project no. N N303 414037 for 2009-2014).

\section{REFERENCES}

Aртroот A. 2008. Lichens of St Helena and Ascension Island. Bot. J. Linn. Soc. 158: 147-171.

Bungartz F., Hillmann G., Kalb K. \& Elix J. A. 2013. Leprose and leproid lichens of the Galapagos, with a particular focus on Lepraria (Stereocaulaceae) and Septotrapelia (Pilocarpaceae). Phytotaxa 150(1): 1-28.

Ekman S. \& Tønsberg T. 2002. Most species of Lepraria and Leproloma form a monophyletic group closely related to Stereocaulon. Mycol. Res. 106(11): 1262-1276.

Elix J. A. 2006. The chemical diversity of Lepraria coriensis and L. usnica (lichenized Ascomycota) in Australia. Australas. Lichenol. 58: 24-26.

Flakus A., Elix J. A., Rodriguez P. \& Kukwa M. 2011. New species and records of Lepraria (Stereocaulaceae, lichenized Ascomycota) from South America. Lichenologist 43(1): 57-66. 
Grube M., Baloch E. \& Arup U. 2004. A phylogenetic study of the Lecanora rupicola group (Lecanoraceae, Ascomycota). Mycol. Res. 108(5): 505-514.

Hodkinson B. P. \& Lendemer J. C. 2013. Next-generation sequencing reveals sterile crustose lichen phylogeny. $M y$ cosphere 4(6): 1028-1039.

Kukwa M. 2006. Notes on taxonomy and distribution of the lichen species Lepraria ecorticata comb. nov. Mycotaxon 97: 63-66.

Kukwa M. \& Pérez-Ortega S. 2010. A second species of Botryolepraria from the Neotropics and the phylogenetic placement of the genus within Ascomycota. Mycol. Progr. 9(3): 345-351.

LAUNDON J. R. 2003. Six lichens of the Lecanora varia group. Nova Hedwigia 76(1-2): 83-111.

Lendemer J. C. \& Hodkinson B. P. 2013. A radical shift in the taxonomy of Lepraria s.1.: molecular and morphological studies shed new light on the evolution of asexuality and lichen growth form diversification. Mycologia 105(4): 994-1018.
Nelsen M. P., Lumbsch H. T., LÜCKIng R. \& Elix J. A. 2008. Further evidence for the polyphyly of Lepraria (Lecanorales: Stereocaulaceae). Nova Hedwigia 87(3-4): 361-371.

Orange A., James P. W. \& White F. J. 2001. Microchemical methods for the identification of lichens. British Lichen Society, London.

Osyczka P., Kukwa M. \& Olech M. 2010. Notes on the lichen genus Lepraria from maritime (South Shetlands) and continental (Schirmacher and Bunger Oases) Antarctica. Polar Biol. 33(5): 627-634.

SAAG L., SAaG A. \& Randlane T. 2009. World survey of the genus Lepraria (Stereocaulaceae, lichenized Ascomycota). Lichenologist 41(1): 25-60.

Sipman H. J. M. 2003. New species of Cryptothecia, Lepraria and Ocellularia (Lichenized Ascomycetes) from Singapore. Biblioth. Lichenol. 86: 177-184.

Sipman H. J. M. 2004. Survey of Lepraria species with lobed thallus margins in the tropics. Herzogia 17: 23-35.

Received 13 January 2013 